\title{
Manioc-stem transects: vital flows, technical processes and transformations
}

\author{
Alessandro Roberto de Oliveira ' \\ - Universidade de Brasília (UnB), Brasília/DF, Brasil
}

\begin{abstract}
This article studies human-plant relations as technical phenomena in the context of the pluriethnic communities of the border between Brazil and Guyana. It proposes that we consider a technogenesis of the social at the intersection of technical processes and vital flows of manioc stems - the overground part of the plant that produces manioc (Manihot esculenta). Its starting point is a Wapichana agriculturalist's collection of stem segments. The onomastics of this set provides an idea of the diversity of these plants in the region. However, the article argues that, rather than being referents in a closed classificatory system, names are histories, indexes of ways of knowing and processes of individuation of people and varieties. By emphasising processes of stem manipulation, the article discusses some of the methodological challenges of the ethnography of technique and reflects on contemporary social transformations in dialogue with Indigenous analyses.
\end{abstract}

Key words: Human-plant relations; technogenesis; manioc stem networks; techniques; vital flows. 


\section{Transecto maniva: \\ fluxos vitais, processos técnicos \\ e transformações}

\section{Resumo}

O artigo aborda as relações humano-planta como fenômeno técnico no contexto de comunidades pluriétnicas que vivem na região entre o Brasil e a Guiana. Propõe considerar uma tecnogênese do social na interseção entre processos técnicos e fluxos vitais de manivas - a parte aérea da planta que produz a mandioca (Manihot esculenta). O ponto de partida é a coleção de hastes de uma agricultora wapichana. A onomástica desse conjunto oferece uma ideia acerca da diversidade destas plantas nessa região. Contudo, o argumento é que os nomes, menos que referentes de um sistema classificatório fechado, são histórias, índices de modos de conhecer e de processos de individuação de pessoas e variedades. Ao enfatizar os processos de manipulação de manivas discute alguns desafios metodológicos da etnografia da técnica e reflete sobre as transformações sociais contemporâneas em diálogo com análises indígenas.

Palavras-chave: Humanos-plantas; tecnogênese; redes manivas; técnicas; fluxos vitais. 


\title{
Manioc-stem transects: \\ vital flows, technical processes and transformations
}

\author{
Alessandro Roberto de Oliveira
}

\section{Introduction}

Different theoretical tendencies in anthropology are rethinking the main assumptions and conceptual categories in use in the discipline. Analysis based on dualities or oppositions, such as nature/culture, subject/ object, individual/society, have been criticized and reviewed. In one direction, we have questioned the attribution of the "social" to a specific parcel of reality, that which pertains to the human, built out of material, biological, psychological and economic raw materials. In place of this exclusively human ontological province, actornetwork theory redefines the "social" as the name of a movement, a displacement or transformation that links or associates humans and non-humans within the course of actions (Latour 1994, 2005). In an ecological paradigm, Tim Ingold (2000) has argued that humans are immersed in a world of life within an environment, countering the idea of the environment as the cultural construction of nature. He shows that life occurs through flows within a relational atmosphere, following the precept that things are in life, rather than vice versa (Ingold 2011).

Since the work of Marcel Mauss, 'technique' has been a privileged category for understanding these movements or flows that appear to be central to contemporary theoretical proposals. The intrinsically social character of technique allows us to envisage a society's ways of acting without having recourse to representations or symbolism, since techniques are specific modes of practical engagement in the concrete procedures of living that amount to, in Mauss' definition, traditional and efficacious acts with physical, chemical and mechanical effects. In a development of the Maussian project, André-Georges Haudricourt (2013) analysed human ways of acting toward animals and plants as a means to uncover patterns of relations that are independent of the nature of the beings involved, whether human or otherwise. Haudricourt argued for the existence of homologies between human behaviour toward sheep and buffalo, cereal and yams, and the relations established with other humans. He was not attempting to project technical relations onto social relations, but to draw attention to the challenge involved in apprehending the propagation of the ways of relating that are constitutive of the social. Haudricourt even formalized a typology of technical action, recently updated by Carole Ferret (2012), concerned with human ways of acting that include the potential of other beings, such as animals and plants, to act as well.

This article is concerned with ways of relating that are constitutive of the "social" through the intersection of technical processes and vital flows in human-plant relations in the agricultural practices of pluriethnical Indigenous communities that inhabit the Serra da Lua region, on the border between Brazil and Guyana'. It explores the theoretical and methodological possibilities of 'technique' as an analytical category in order to apprehend the "social" from an ontogenetic perspective. The ethnographic focus is on the maniva the overground part of the manioc plant. The circulation of these cuttings is an important aspect of the

\footnotetext{
Human-plant relation were a recurring theme during my fieldwork. Initially, I sought to understand the daily, contentious use of poisonous plants as a fishing technique (Oliveira 2015). More recently, I studied ways of acting related to a category of plants in aggressive shamanic practice (Oliveira 2018).
} 
networks of relations in these communities. As I will show, the stem segments also condense ways of knowing (Barth 1995), relations and social values, as they move between human groups and garden environments, production and consumption, throughout this region.

The work of Haudricourt invites us to consider a technogenesis of the social, in that technical processes are themselves generative of societies insofar as they mobilize a multiplicity of beings, materials, people, plants, rhythms and forces of the cosmos that give shape to communities and configure ways of life. In dialogue with the ethnography of the Guianas, I develop the idea that Indigenous practices involving manioc stems materialize ways of constituting collectivities and express values and dispositions of a way of life and a "sense of community" (Overing 1991).

The classic ethnological model for explaining the social organization of the Indigenous people of the Guianas (Rivière 2006 [1984]) projected an image of fluid, unstable, simple, atomized and minimalist native societies which were based on a political economy of the scarcity of resources and, above all, of people (Viveiros de Castro 1986). However, as Overing observed, egalitarianism and an aversion to relations of subordination, a degree of disdain for local processes of collective decision-making, attitudes to property, work, and personal autonomy, all constitute a political creed, a social and aesthetic value that can only be understood through a specific sense of the "social" and of the role of "productive knowledge" in the incessant process of constructing a political and moral community. ${ }^{2}$ Recently, studies included in Gallois (2005) have also questioned a model based on socio-spatial atomism and scarcity, mustering the concept of the "network" to displace a localist and "ethnic" lens toward relations, including relations with nonhumans.

Taking this discussion forward, articulating the Latourian notion of the network as a way of understanding movements and relations with the value of "life" in Ingold's ecological paradigm, this article emphasises technical processes "understood as the ordered assembly of a plurality of acts [that] can be treated as the privileged object for understanding the complexity of vital processes" (Pitrou 2016:7). Through an anthropology of technique, I will explore the technogenesis of this specific sense of the "social" by registering what the intersections of vital flows and technical processes reveal about human-plant relations on a regional scale. Assuming that "knowledge" is not a unitary, abstract and generalized concept, since any human group shares divergent bodies of knowledge and different ways of knowing, we are moved to pay close attention to the processes that generate variations in knowledge and on those knowledgeable of their acts, through their activities and networks (Barth 1987, 2000).

The ethnography will delineate three circuits of activities that are generative of networks of collecting, of techniques for transforming these plants into diverse products, and of relational transformations intrinsic to these movements. In the first circuit I present the collection of cuttings belonging to a Wapichana woman who lives in the Jacamim community, in the Serra da Lua region. This fragment of a collection raises certain correlations between a person's biography and her cuttings and allows us to approximate them to proper ways of knowing these plants.

In the second circuit, I foreground an ethnographic slice of the tangle of material flows, establishing two definite points in the technical process that, in my view, yield important insights into human-plant interactions. From cutting the stem, through planting, to the consumption of the manioc beer (caxiri) with the work parties (ajuris) that gather to create a new garden, after which the cycle starts anew with the cutting/ selection of new stems for replanting. My aim here is to focus on the ethnography of ways of acting as they are put into practice in human-plant interactions, and to demonstrate the "social" that these processes render visible during different phases of the manioc stem's being. The production and consumption of the beer conveys values that are materialized in this process.

2 The category of "productive knowledge" does not only refer to capacities that enable the use of land resources, but also to those that enable tact, skills for living peacefully and sociably, in daily interactions with others (Overing 1991). 
These values are also present in the third circuit, the flow of industrial merchandise and the consumption of products acquired in the city. The concatenation of these three circuits highlights Indigenous analyses of (practical, moral, political, economic) aspects that are indivisible from the production and consumption of food in a context of socioeconomic pressures from the market and from public policies that tend to reduce daily engagements in activities of cultivation.

\section{Human-Plant relations in the Brazil-Guyana border}

The Serra da Lua region is situated in the ethnographic area of the western Guianese shield (Melatti 2010), which stretches from the highlands of southern Venezuela to the border between Brazil and Guyana. It is characterized by a heterogeneous environment (dense forest, mountain ranges, savannah and open fields known regionally as lavrado) and a significant sociocultural diversity. What unites the region as an "ethnographic area" are the networks of commercial exchange and circulation of knowledge (Colson 1985) that connect different Indigenous people to each other, and to different segments of the non-Indigenous population, in some cases over a long period of time. Ethnonyms express relative degree of social distance in an identity system that has long been articulated by inter-marriages and the existence of mixed villages and by the proximity of village from different ethnic groups (Santilli 1994).

In this landscape, composed of networks of exchange between different Indigenous people and the nonIndigenous population, characterized by the fluid character of ethnic borders, any approach the separates societies or "ethnic groups" into discrete cultural or linguistic units hinders an understanding of the complex of relations that configure this area, where the transnational, the national, and the ethnic coexist in a dynamic, ambiguous and paradoxical way (Baines 2005).

In the Serra da Lua region, Indigenous communities are mostly made up of Macuxi and Wapichana. These collectivities have lived through a violent history of territorial expropriation and the imposition of an international border which tore through the traditional lands of their ancestors. Throughout this region, we find the intense movement of groups and people. These dynamic movements occur for several reasons, including the: ecological (rotation of cultivated areas, availability of hydrological resources), economic and political (state institutions of healthcare and education, formation and fission of groups), and/or cosmological (sorcery, disease, death).

Anthropology has had to develop new conceptual and methodological tools to investigate these multicommunity and multi-ethnic contexts. ${ }^{3}$ An emphasis on the networks of relations allows us to amplify the analytical meaning of the notion of the "border" beyond its territorial and/or moral attributes, and to reposition it as a space of mediation, a mechanism of communication and exchange that relates different ethnic communities or local groups, as well as forces of the cosmos (Gallois 2005).

However, through the daily engagements of specific people in specific landscapes, relational networks are always seen to be segmented in local experiences and particular localizations. In this sense, a technical approach can be a fruitful way for ethnographically understanding how these networks are woven in their movement and flows, privileging technical processes as an ordered group of actions developed by a specific human group out of their knowledge of living beings, such as, for example, plants and their vital processes.

\footnotetext{
3 Ever since Radcliffe-Brown, the term "network" has been used by social anthropology to refer to the set of concrete relations between individuals and groups that constitute the social structure, or the society. Despite critiques of the social theory that underscores this view (Leach 1996 [1954]), the concept of the "network" continued to be used as a descriptive metaphor, and as a means for apprehending and analyzing social relations and political processes (Barnes 1987). In the last decades, the concept has been redefined by Bruno Latour $(1994,2005)$ as a path to revising the very theory or model of the "social". The Latourian network is a heterogeneous assembly, gathering within it humans and a host of other aggregates (genes, microbes, plants, soil samples). As he claims, the network is a tool that "helps us to describe something, and not something that is being described" (Latour 2005: 192).
} 
Through this ethnographic literature, and particularly through fieldwork, I realized that plants participate in different modalities of human knowledge, creating and mediating relations. Human-plant relations provide a privileged means for understanding Wapichana territoriality, moving from the house floor, through places of cultivation, and into the forest. ${ }^{4}$

Wapichana knowledge of the living beings that we generally call "plants" is highly refined. Nádia Farage (1997) identified three botanical categories, structured through modes of human-plant relations: karam makao - wild plants that grow in the forest; wapao ribao - domesticated and cultivated plants in the garden; and wapananinao - plants that are neither cultivated, nor wild. The wapananinao grow and live in environments that they choose, for they possess the same principles of intentionality as humans do, and are distinguished from the remaining categories for possessing and generating magic. In this system, the criterion of cultivation defines the differences between the classes.

The plants with which I am concerned in this article belong to the second category. Narrative knowledge situates their origin in the felling of a large tree from which everything grew, leading to a rupture of the originary order, which had been characterized by a lack of differentiation between species. After being felled, the tree spread out its multiplicities, instating not only differentiation, but also another way of reproducing plants through the human work of cultivation. This registers a founding characteristic of the human condition: the need to cultivate plants to live, and cultivated plants as a metaphor for the state of society (Farage 2002: 518).

During my research I sought out how these cosmological, structural and classificatory references could be encountered in contexts of practical engagement of people in different environments, where the passage from one domain to the other can be achieved without transposing limits. I therefore considered the possibility that these delimitations did not exist, thus avoiding the dichotomy between cosmology and practice, or even that between society and nature.

This approach to the karam'makao category drew me to the growing literature on agrobiodiversity, particularly on research and political discussion stemming from the objectification of a "traditional agricultural system" in the Rio Negro region (Emperaire 2001, 2002, 2010; Eloy and Emperaire, 2008; Emperaire, Velthem \& Oliveira 2008, Santilli 2012, Fagundes 2014). In what follows I develop these approximations through the critique of systemic approaches in the field of the anthropology of technique (Mura 2011).

\section{Traditional agricultural systems as technical phenomena}

Manioc is considered a central element in the dynamic of the "agricultural systems" of various traditional people and communities in Brazil, both for its resistance to different climate and soil conditions, and for its diversity, the variety of products that can be made from it and the sociocultural value attributed to its cultivation. In recent years, relations between humans and manioc has been the focus of policies of heritagization of immaterial culture codified as traditional agricultural systems (Fagundes 2014).

The literature on manioc cultivars is particularly dense for Northwest Amazonia. A number of studies have highlighted the relation between the intraspecific diversity of manioc and the means used by Indigenous groups to maintain and enrich this diversity, demonstrating the relevance of human relations for manioc

\footnotetext{
4 The Wapichana are the only Arawak-speaking people in the fields of the interfluvial zone between the Branco and Rupununi rivers, a region that is politically divided between Brazil and Guyana. At present they number some 14,0oo people, 7,832 in Brazil and 6,00o in Guyana, along with some families in Venezuela (Oliveira, 2012). In Brazil, the largest Wapichana population is in the Serra da Lua. On the Guyanese side, their villages occupy the savannahs of the Rupununi, Tacuto and Kwitaro rivers, with the Kanuku mountains as a northern limit, separating them from Macuxi territory. To the south, their territory approximates Waiwai lands. Many Wapichana who live on the Brazilian side of the border consider the lives of their kinspeople in Guyana to be more traditional, since they still use timbó poison for fishing and live amidst the most powerful sorcerers (Ávila 2006).
} 
propagation (Chernela 1987). In the last few years, this research has been reinvigorated by a set of studies in anthropology, biology and forestry on the importance of the biological diversity of the alimentary species that are cultivated by traditional populations (Eloy and Emperaire 2008, Emperaire, Velthem \& Oliveira 2008).5

This research has stressed the importance of these agricultural practices not only from a strictly productive point of view, but also because of their specific cultural dimensions and the universal-heritage aspects that are involved, thereby emphasizing how knowledge constitutive of agricultural systems are fundamental guarantees for in situ evolution and genetic improvement.

According to Emperaire, Van Velthem and Gita de Oliveira (2008), the expression "agricultural system" is used in a restricted sense. Two main levels of analysis are distinguished in this field: (a) the system of production investigated at the scale of the unit of production (generally the domestic unit) which comprises different subsystems according to activity (agriculture, animal husbandry, extractivism); (b) the level of the agrarian system, a theoretical modelling of the regional scale based on the combination of the different production systems in existence. The expression "agricultural system" in this latter sense avoids a pre-defined analytical model centred on aspects linked to the productive capacity which are embedded in the former sense, and enables multiple readings of the object under study. In the context of studies of Indigenous agriculture in the Rio Negro, the authors provide a wider operational definition:

we understand agricultural systems to be the set of knowledge, myths and reports, productive practices, techniques, artefacts and other associated manifestations that involve managed spaces and cultivated plants, ways of transforming agricultural products and local alimentary systems. In other words, it refers to the complex of knowledge, practice and social relations that are enacted in the garden, or even in the forest, and covers food and the many ways it is consumed in diverse contexts of social life (Emperaire, Velthem \& Oliveira 2008: 03)

This definition is interesting since it allows us to envisage these "systems" not only in terms of their productive base and nutritional function, but, in a wider sense, to consider the correlations between the different cultural and social aspects that make traditional agricultural activities into a system that articulates families and communities through the flow of persons, stories, plants, techniques and their products.

My first observation is that this definition implies action, flows and movements that are stabilized by approaches that privilege classification, structure and the cultural meanings attributed to the system. Lucia van Velthem (2012), for instance, analysed the material expression of the agricultural system of the Rio Negro with an ethnographic focus on the artefacts that enable the cultivation and processing of manioc. In dialogue with studies of material culture, she turns to debates on the notion of the object and explores the meanings and functions of tipitis, baskets, sieves and graters in the relations they establish among themselves and with those who make and use them in the hearth house. Within the material repertoire of the agricultural system of the Baré, van Velthem notes the importance of the carrying basket as a "witness object" of a way of life. She steers the discussion into the field of heritage and cultural identity represented by these artefacts and the questions raised by the rupture of the processes of knowledge transmission related to their fabrication and use in practices of transforming manioc.

The analytical procedure I develop in this article goes in a different direction. Instead of emphasizing artefacts or tools as witnesses to the "system", I explore the material flow and plurality of technical acts through which manioc stems participate in vital flows and cycles, and how, in their different phases, they

\footnotetext{
5 The Indigenous Council of Roraima (Conselho Indígena de Roraima) surveyed the traditional seeds produced in the Hill Regions (CIR/PDPI/MMA, 2006). Another important initiative in recent years was the Wazaka'ye guyaagroflor (2008-2010) project, which aimed to develop sustainable strategies for the agricultural systems and to strengthen the economy and organization of Indigenous and Maroon communities in Suriname, Brazil and Venezuela. For the results of the project, see Pinho (2008).
} 
are transformed into different products, among which is the manioc beer that enlivens collective work parties in spaces of cultivation, which is also when the vital cycle is renewed.

This requires rejecting, from the start, some of the ontological divisions implicit in the systematic approaches characteristic of studies of "material culture". It also implies a critical review of certain anthropological studies of technique, so as to eschew comprehending it only as action upon matter. It is necessary to realize that "technique is not what happens between the human subject and the environment, mediated by artefacts, but a given relation between movements and things, which comprises tools, bodies and environments" (Sautchuk 2015: 129).

This understanding of technique derives from Mauss' work where technique is defined as a sort of physiopsycho-sociological montage deemed to be traditional and effective (Mauss 2003). The human body itself is thus considered an object or a technical medium, mobilized in an organized and traditional set of movements and acts, most of which are manual, and which converge to achieve a physical, chemical or organic aim (Mauss 2009).

Following Mauss, different authors have approached technique as a system. Lemonnier (1986, 1992), for instance, argues that to understand technique in all of its aspects of action upon matter, it is necessary to understand it through a systemic perspective; that is, as a technical system articulated at different levels. In a first level, every technique, arbitrarily defined, is the locus of multiple interactions and constant adjustments among a set of elements such as materials, energy, gestures, artefacts and knowledge. In a second level, for a specific society, various techniques refer to each other through principles, resources and/or common products configuring technical systems proper. Finally, the set of cultural representations and, particularly, the classifications of techniques by a specific group, act to strengthen its systemic character. Technical systems can thus be discussed in these three planes: through the dynamics of interaction between the components of technique; through the interrelations between diverse techniques; and through the relations between technique and other social phenomena. Lemonnier, for example, focuses his analysis on the social representations and the determination of technical choices by symbolic systems.

In a review of this paradigm of the anthropology of technique, Mura (2011) notes the resilience of an "ontological contraposition" in the ideas of set, collectivity and system, between the domains of "Nature" and the "Human". On the one hand, the composition of physical and chemical elements related to each other via biophysical factors compose the material world; on the other, there is the expression of a sociocultural world or a specific symbolic system. These two orders of reality are then connected by the procedure of analysing them as a "system".

To overcome this ontological partitioning of reality, Mura sketches an alternative approximation to the systemic approach by adopting an ecological paradigm and a processual view of technical phenomena. It involves paying ethnographic attention to the concrete processes of the concatenation of diverse elements, configurations where the division between "natural" and "sociocultural" is not all that useful for understanding technical phenomena. This approximation also recognizes that techniques are organized in "systems", in the sense that every technical process maintains an internal coherence that can be registered by ethnography. The difference of a processual approach consists in abandoning the artifice of a "systemic" composition deriving from presumed or predetermined orders. The author proposes that technical processes not be understood as systems made up of combinations of closed or predefined totalities, but rather as open configurations in permanent transformation, formed by the continuous flow of elements, forces, materials, energies and knowledge mobilized in specific forms of concatenation. Taking technical acts as processes implies apprehending a group of movements that enables the formation of operational sequences and concatenations of these sociotechnical systems (Mura 2011). 
As I see it, this approach opens up new possibilities for an understanding of technical and vital processes according to conceptual universes that differ from a Western framework. However, this processualist approach retains an interactionalist character that can be refined. By directing the anthropological gaze to the concatenation of elements, we must query the very unity of these elements - or, in other words, ask how materials, subjects and objects of action occur in the flows that constitute them. What I am proposing here is that, with technical processes, relations do not quite occur between elements, but rather than such elements emerge from concatenations.

This emphasis on relations draws inspiration from Gilbert Simondon (2005). This philosopher of techniques developed a set of notions that are interesting theoretical resources for an ethnographic approach to technical phenomena, particularly those that bring humans and plants into association. One of these is the idea of individuation. Starting from a critique of "the ontological privilege of the constituted individual" which is common to atomist substantialism and hylomorphism, Simondon calls attention to the occurrence of "obscure zones" in the physical, biological and social constitution of the operations of individuation, through which the individual comes to exist. These operations reveal living beings and technical objects, as partial resolutions of themselves, as tense systems, nodes of communication. The technologician must foreground the technical ontogenesis of beings, apprehending the "unfolding of his reality, and knowing the individual through individuation rather than individuation through the individual" (Simondon 2005 [1958]:24).

I find this an instigating proposal for thinking of "traditional agricultural systems" as a technical phenomenon, and the manioc stem as a phase of its own being, which incessantly flows, transforms, and individuates as partial solutions to its very integrity. As I will show, this resonates with how the people I lived with order their collections in an always provisional and contextual manner, where named differences are defined and redefined without apparently upsetting a supposed classificatory system that persists in a language. This proposition also has implications for the ethnography of technical processes, particularly for the lacunae that emerge in any description.

\section{Naming as histories of individuation}

Manioc can be reproduced from seeds dispersed by the wind or by insects such as ants. The seeds have their "dormancy" interrupted by fire, generally set by humans while opening up spaces for cultivation. Another important means for propagating manioc is through stem cuttings that are planted and enable vegetative reproduction. These stems are selected, classified, experimented with, and, at least in the area of the Guianas under study, circulate in networks of relations that range from family groups and neighbouring gardens to more distant communities and cultivated areas, weaving a web that connects collectivities within a wide regional system.

In these communities, every family unit possesses its gardens and houses, men and women make up conjugal pairings that produce practically all of the foodstuffs needed for a rich diet (banana, maize, rice, papaya, sugar cane, beans, peppers, potato, pineapple, pumpkins, yams and watermelon). Together, they own all of the artefacts and material goods needed for maintaining the family, thus constituting largely autonomous domestic units, founded and reproduced through the work of its members.

The first agricultural tasks required for new cultivated areas - felling and clearing felled ground - are the preserve of men, with the participation of women. With planting and subsequent activities, the garden becomes a predominantly female space. It is women who keep gardens clean, clearing underbrush and monitoring for pests and other threats to cultivated plants. They also manage harvesting and oversee the preparation of food and fermented drinks that attract kinspeople, enabling the constant renovation of cultivated spaces and of the relations between people themselves. 
Knowledge of cultivation, intraspecific diversity and the best use of each varietal in the production of food is a part of daily life. A first approach to understanding these ways of knowing is through the names of the manioc stem varieties used regionally. This nomenclature is the means for revealing the assumptions involved in the processes of identification, selection, experimentation and circulation that are used, most of all, by women.

During work developed by Indigenous Territorial and Environmental Agents (Agentes Territoriais e Ambientais Indígenas (ATAIS)), we surveyed the variety of manioc stems that existed in the Jacamim community. The results were surprising: during a brief activity with the agriculturist Mrs Celestina, we were able to identify 25 varieties that, at the time, she cultivated in her garden! Mrs Celestina has relatives "scattered" (esparramado) through the Serra da Lua region and into the Rupununi Valley - which she visits, mostly during the end of year festivities and other dates considered important in the region.

In Jacamim, we gathered information on 25 manioc stems, distinguished by the colour of the manioc (the root), the casing (brown, white, red and reddish), stature (tall, short, medium) and the colour of the stem (the overground part of the plant), the format of the leaves (thin or thick), the presence or absence of branches, and, in some cases, the products that could be derived from them. Practically all varieties are planted at the start of winter in clay soils. But there are also varieties planted in the middle or even the end of the rainy season, and some varieties more suited to "red" soils and "hill forest".

The value attributed to yellow manioc, mostly linked to their quality for producing farina, is an interesting aspect of the sample. Some inhabitants claim that, until recently, there had been a significant quantity of white manioc, which was gradually discarded in favour of the higher quality farina produced from yellow varieties. These observations indicate that, alongside the value attributed to diversity itself, there are pragmatic criteria based on the quality of the final product. 
Manioc, stems and their products

\begin{tabular}{|c|c|c|}
\hline Manioc & Name of the stems & Good for \\
\hline \multirow[t]{7}{*}{ Yellow } & $\begin{array}{l}\text { Bakyray (Collared peccary) } \\
\text { Baip (Duck) } \\
\text { Irudadap (Leptotila) }\end{array}$ & $\begin{array}{l}\text { Only for bread } \\
\text { Farina and beer } \\
\text { Farina, bread and beer }\end{array}$ \\
\hline & $\begin{array}{l}\text { Kamynaryp (Aracu fish) } \\
\text { Kadadap } \\
\text { Amazona }\end{array}$ & $\begin{array}{l}\text { Farina and beer } \\
\text { Farina and beer } \\
\text { Farina and beer }\end{array}$ \\
\hline & $\begin{array}{l}\text { Mekuryn } \\
\text { Zinip } \\
\text { Kuray Kuray }\end{array}$ & $\begin{array}{l}\text { Farina } \\
\text { Farina and bread } \\
\text { Farina, bread and beer }\end{array}$ \\
\hline & $\begin{array}{l}\text { Wixap } \\
\text { Pireira }\end{array}$ & $\begin{array}{l}\text { Farina } \\
\text { Farina }\end{array}$ \\
\hline & $\begin{array}{l}\text { Mucumucup } \\
\text { Karaudazyp } \\
\text { Buzuwap }\end{array}$ & $\begin{array}{l}\text { Farina, beer and starch } \\
\text { Farina, beer and starch } \\
\text { Farina, beer and starch }\end{array}$ \\
\hline & Azip & Farina, beer and bread \\
\hline & $\begin{array}{l}\text { Kuxarap } \\
\text { Tybary awyn }\end{array}$ & $\begin{array}{l}\text { Farina and beer } \\
\text { Farina and beer }\end{array}$ \\
\hline White & $\begin{array}{l}\text { Manarip } \\
\text { Kiz pii } \\
\text { Sabin } \\
\text { Charip } \\
\text { Sweet manioc } \\
\text { Seed } \\
\text { Butter sweet manioc }\end{array}$ & $\begin{array}{l}\text { Bread and beer } \\
\text { Only bread } \\
\text { Bread and beer } \\
\text { Bread } \\
\text { Bread, starch and cooked } \\
\text { Bread and starch } \\
\text { Beer and bread }\end{array}$ \\
\hline Red & Kyryk danip & Farina \\
\hline
\end{tabular}

As Emperarie (2002) has observed, the notion of 'variety' is not a general and self-same referent with a logical definition. Classification varies according to region, context, interested person, degrees of knowledge, and the emphasis of certain criteria in a classification event. The cultivated varieties and species are biological objects that conform to cultural criteria of production, denomination and circulation, constantly readapted to ecological, economic, and sociocultural contexts. Hence the local conceptualizations of "variety" are themselves different and may not necessarily correspond to a scientific conceptualization of variety or clone.

Instead of discussing Indigenous taxonomies by way of a small sample, what interests me here are the names and their flows. I will highlight how this small set contains clues about ways of knowing - forms of identifying and selecting developed in the region. These names bolster an understanding of the importance of vital flows, since they indicate certain aspects of the movement of stems between communities, providing evidence of the life-trajectories of plants (Emperarie 2010) and people. 
Linguistic difference is important. Often, the stems have names in Portuguese which are shared by the Wapichana; that is, they identify the same variety by the same category in the Portuguese language. In some cases, for other varieties, there is a specific nomenclature in the Wapichana language that differs from the one in Portuguese. There is a third set of stems which do not have a name in Portuguese, only in Wapichana.

Regarding this later set, non-Indigenous agriculturalists may conceivably know these varieties by different names, or perhaps these varieties have been exchanged between Indigenous and non-Indigenous agriculturalists, and thus exist independently in parallel systems of classification. Alternatively, it is possible that some varieties which are designated only in Wapichana do not circulate among non-Indigenous agriculturalists, and are thus known only to Indigenous agriculturalists and managed exclusively by them. This hypothesis leads us imagine the importance of work in the maintenance and improvement of these varieties, in that we must recognize the work of Indigenous agriculturalists in the maintenance of in situ biological diversity, a fundamental activity in the framework of western concerns about the future of food availability worldwide (Santilli 2012).

Contrasting Mrs Celestina's collection with those of other women in the region, what most drew my attention was the flexibility of the names. In the onomastics of manioc stems, some varieties are named by analogy with other elements of biodiversity, such as animals, Bakyray (collared peccary), Baip (duck) and birds, such as the Irudadap (Leptotila). Some varieties with names only in Portuguese are seen to result from exchanges with non-Indigenous people, and/or were acquired in the city. Speaking with other people in the region, such as in Malacacheta, we found varieties with names such as Amazonas and Maranhão (names of Brazilian States). There are also varieties known as amarelão (big yellow), jaca (jackfruit), folha fina (this leaf), seis meses (six months), acode fome (hunger aid, a faster growing variety), jacaré (caiman, its casing looks like caiman skin), seringueira (Hevea tree), Maracañ̃ (mini-macaw), tucumã (a palm species), brabinha (little aggressive variety, good for making beer) and sabiá (from Sabiâs longhouse). Concerning this latter stem, an inhabitant of Malacheta said it was the same as "Amazonas", but since she acquired it at Sabiâ's longhouse, she thought it best to identify it with a name that was meaningful to her, assuming that whoever had named it "Amazonas" had followed the same principle.

In Mrs Celestina's collection, three varieties draw attention for their geographical references, which point to places in Guyana: manarip, charip and karaudazyp. The suffixes rip and zip in these varieties is derived from the word for 'manioc', which is written Kanyz. What precedes or succeeds this affix can be understood to be a reference to the general quality of the species. Karaudazyp, for example, is a direct reference to the Wapichana community of Karaudarnau, in the Rupununi Valley. Charip is a reference to Wichabai, another community situated to the northwest of Karaudarnau. Manarip alludes to another, yet more distant, community, Maroranao, in the Essequibo River Valley. This small fragment reveals the extent of Indigenous networks of exchange, experimentation and maintenance of intraspecific biological diversity that the collection of a single agriculturalists can reveal, projecting an image of the radius in which these cultivars circulate,

These naming practices can be understood through the difference between classificatory and narrative knowledge proposed by Tim Ingold (2015). While the former groups things based on their intrinsic characteristics, regardless of their localities, the latter singularizes people and things, in the sense that to know a thing, an animal, a place or a plant, is to know its history. Not unlike the Koyukon of Alaska, who name their clans after animals based on histories and characteristics of behaviour, I would venture that the practices of naming manioc stems follows a similar trail, so that, in contrast to a closed classificatory system that is shared collectively, each person, by virtue of their biography, is free to name their collections without concern for fixing a stable label. Instead, they describe the relations that the stem materializes, singularizing people within this web of knowledge. 
In the following section, I turn to the second circuit, which consists of an ethnographic experiment with the technical process of transforming tubers that have been harvested and separated from the overground part of the plant. While delineating this flow, I discuss some of the ethnographic limits and potentials of 'technique' through use of the notion of 'transect'.

\section{Manioc stem transect}

The studies of technique initiated by Mauss were developed by a succession of researchers in archaeology, ethnology and in material culture studies. Defining technology as the study of techniques involved in human action upon matter, including on the human body itself (Cresswell 1973, Lemonnier 1993), one of the tools elaborated by these studies has been the notion of "operational sequences", originally used to circumscribe interlinked acts in a process of transforming matter. The notion has been discussed by numerous authors focused on describing and reflecting upon technique (Lemonnier 1992, Sigaut (2002 [1994]), Coupaye 2009, 2016).

Defining "operational sequences" can be a useful resource for rendering "technique" visible through the exposition of the enchainment of practices for analysis and comparison. By bringing to the fore certain properties, this procedure helps us reflect on "technical acts", and above all to investigate the activities of humans and "plants" in concrete engagements, such as in agricultural practices. However, the inscription of what we observe as technique is no trivial task, since it involves capturing multidimensional phenomena, that occur across diverse spatial and temporal scales, and that include a host of intervening materials, tools and forces, as is the case with the management of manioc stems. A further difficulty is that, from the point of view of the people who carry them out, technical acts cannot be clearly separated from daily life. Rather, they are immersed in the flow of a range of other activities.

In the last decade, Tim Ingold $(2000,2011,2012,2015)$ has challenged the approach to technical processes based on the analysis of operational sequences as successive orders that can be defined from start to finish. Since establishing the concept of "technical skill" (Ingold 2000: 291) to designate a qualified practice of relating with a "world of materials", the British anthropologist has been elaborating a series of critical interventions to studies of technique. First, he argues that skills cannot simply be considered techniques of the body, in the Maussian sense. Intentionality and functionality should not be considered to pre-exist in the subject or the object, but instead are immanent to the activity itself. Thus instead of isolating the body as a technical object we must contextualize its engagement with a practical environment. Furthermore, skilful practice cannot be reduced to a formula that can be transmitted intergenerationally, and hence it is not amenable to a definitive description.

Similarly, Ingold develops a critique of the studies of material culture. He observes that various studies in this field start from a world of objects removed from the flow of their transformations, so as to attribute agency to them. In a different direction, Ingold proposes that we reintegrate "objects" to the generative flows of the "world of materials", from whence they come and within which they continue to exist, according to the precept that things are in life and not the other way around (Ingold 2011: 29). Ingold (2012) challenges the very notion of the "object" by way of a critique of the ontological primacy of the division between the "material world" and the agency of the human beings which give it form. In lieu of the hylomorphic model that has dominated western thought, Ingold would have another ontology that places emphasis on the flows and transformations of material rather than on the states of matter (Ingold 2012: 26). He thus proposes to think of these processes through the concept of "vital flows", considering that, in his view, the essential relation is not that between matter and form in which the latter is imposed on the former, but, following Deleuze and Guatarri, between materials and forces. He places emphasis on the movement of life and how it constantly recombines, 
redirects the flow of living matter, opening up spaces for creativity in place of a utilitarian perspective. He relies on the writings of Simondon, for whom living matter, far from being passive, is a vehicle of "informed energy" (Simondon apud Ingold 2015:61)

If, on the one hand, the "operational sequence" is a methodological tool that has limitations that can result in deterministic and utilitarian descriptions, and which centre on acts of fabricating things, Ingold's proposals lack clearer indications of how, precisely, they are to be operationalized - or, in other words, we must ask: what must we circumscribe in order to do an ethnography of life? As Pitrou (2016) observes, the universalizing definition of 'life' proposed by Ingold contains an ambiguity, or even a contradiction, in relation to ethnographic interest in other ways of knowing and the possibility of other theories of life. Before we provide a universal definition, it is more productive, and prudent, to resituate the problem before different theories of life through the plurality of vital processes. There is no dearth of orders upon which one can build an ethnographic investigation, from mythologies to ethnoclassifications, through the treatment of animals and plants.

Through his ethnographic work on giant yams among the Nyamikum of New Guinea, Ludovic Coupaye (2009) has sought to update the "operational sequence" as a methodological support for intersecting "technical processes" and "vital flows" (Coupaye 2016). Finding it difficult to study the yams through the methods of the anthropology of technique, Coupaye proposes the use of transects. This concept, which derives from ecology, draws a line between two pre-defined points in a given ecosystem in order to register the species found along the line, taking into account the irregularities of the terrain and topography. When the operational sequence is conceived as a transect, it emerges as a useful resource for cutting through the vital flows so as to make the technical process visible, within the meshwork of life, as a sequence of acts in the different contexts and places where it occurs. Like a line which we can make tense by stretching at different times and in different places, the transect makes visible the heterogeneous elements that are mobilized by people during practice. In this way, the operational sequences of technique can be used as a methodological resource, not so much to produce schematic and utilitarian representations of the execution of mechanical forces on matter, based on predefined logical schemas, but rather to make evident how a nexus of relations is constituted in the flow within which a specific material is transformed, delineating the biography of the different phases of a being.

Each researcher finds his or her own way of making processes visible (graphs, schemes, films, photographic series), to present the sequence of acts, events and places that the technical process reveals. I have opted for a series of photographs that synthesize human-plant interactions through the flow of transformations of the manioc stems into plants, in manioc ground by motors to be roasted into dough, and then broken up again, left to rest so as to ferment, and finally squeezed to become the drink that enlivens people during the planting season. Below, I present this circuit as a sequence of images: 
Figure 1 - Flow of transformations of manioc stems into beer
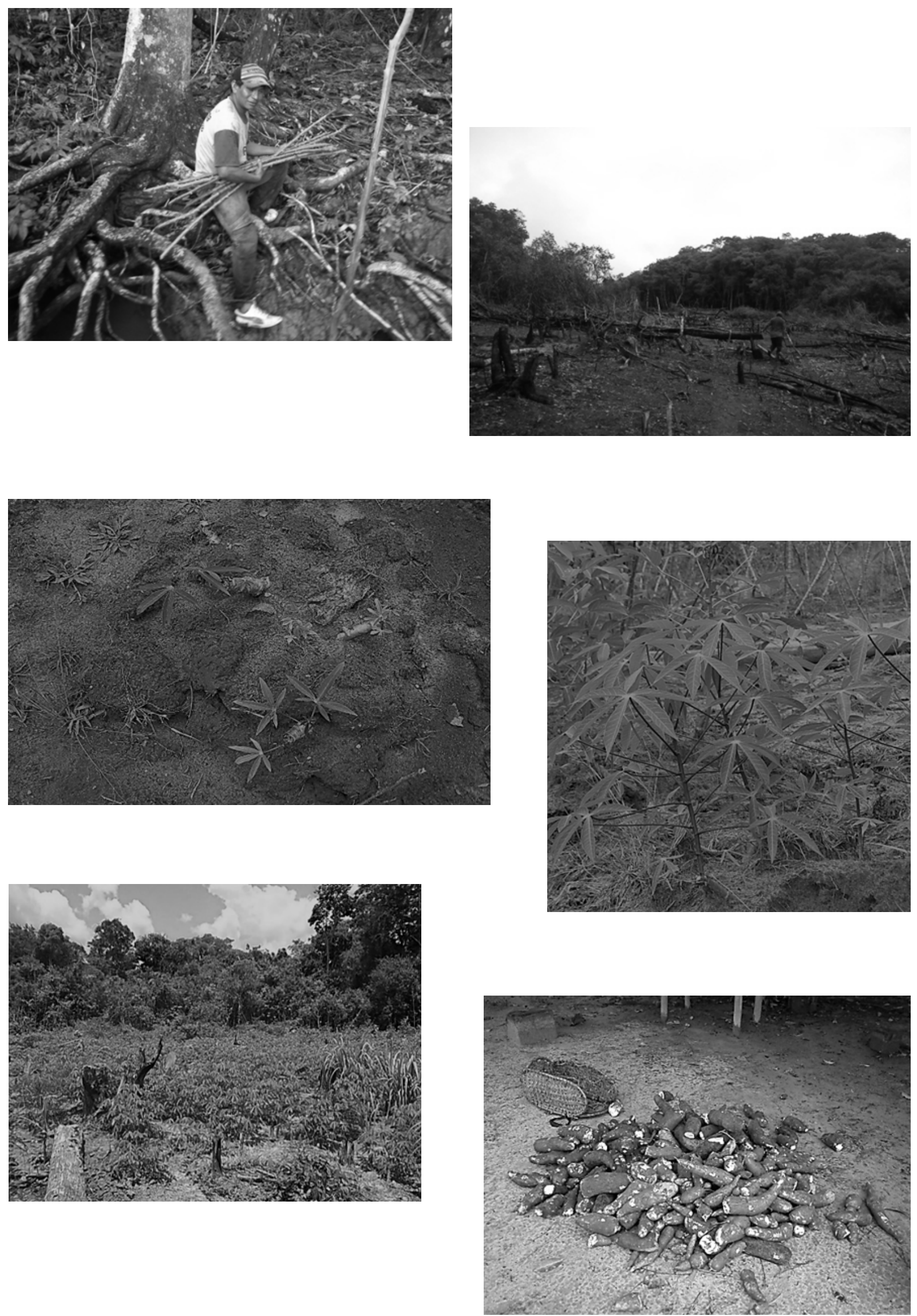

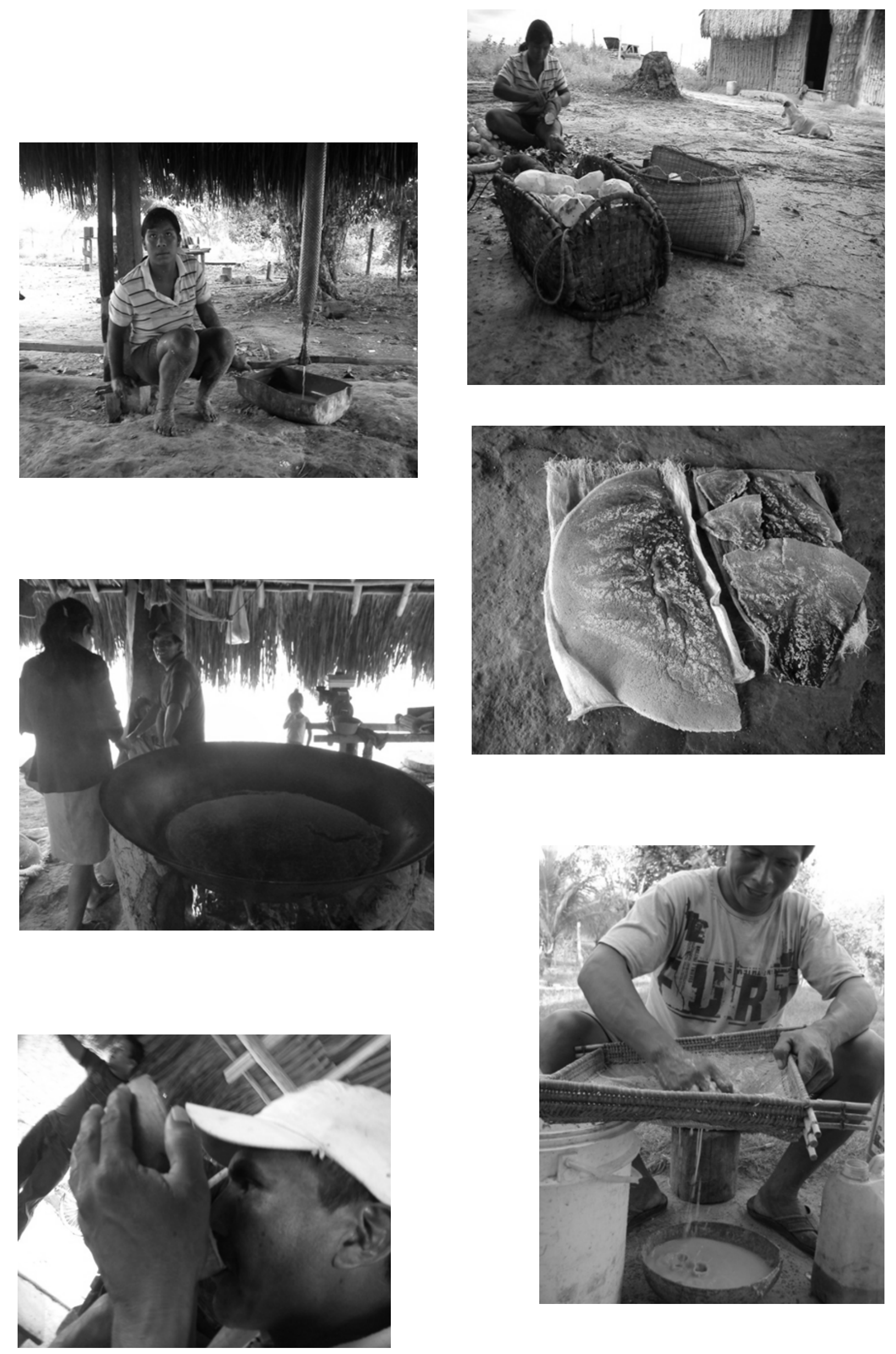
In this circuit, the flow of manioc stems starts and restarts in cultivated spaces. The role of kinspeople in making a garden is fundamental. Parents provide their sons with their first seeds when they open their first garden, lending them their chainsaw and providing gasoline. As they construct their own personal archive, a new couple start to exchange varieties within their kindred. The work parties are organized mostly during weekends, and the couple who owns the garden must always provide beer for kinspeople who are invited to help with work. In these contexts, the beer is generally held in large canisters, and all who participate can take their shares as they work.

During my fieldwork, I participated in some ajuris. In one of them I accompanied Nivaldo, a resident of Jacamim, as he chose manioc stems for planting (first image). On that day, he was gathering his kinspeople and other guests to collaborate with the work of clearing the area for a new garden (second image) and I went with him to the neighbouring garden, which belonged to his brother, where he picked up some varieties. He explained to me some of the criteria he used for selecting which ones he would take: "First you cut it to see if it has milk. If it doesn't have milk it's useless because it won't grow. It is this milk that makes manioc. This milk has starch. To start planting you cut them in the middle for the roots to come out".

The next images show the growth of the plant from the manioc stem. In this movement, the colour of the stem confirms the selection and other experimentations. The growth of a garden planted with stems is collective. People are always mindful of the height-patterns of the garden as the plants grow together (fifth image). When they are mature, they start to be harvested. When they are removed from the earth, the manioc is usually taken to the place where the grater and the oven are kept (sixth image). Once there, the shells are peeled with knives and then the manioc is put through a motorized grater that is operated by combustible fuel.

In the next stage, the starch is squeezed by the tipiti (eighth image). The straw weave is attached to a beam in the roof and packed with starch. The compression of the starch is made possible by the weight of a person who sits successively on a perpendicular crossbar. This movement allows the yellow juice to be eliminated, and with it part of the cyanide $(\mathrm{HCN})$ that is deadly if eaten by humans and animals (including large animals, like cattle), blocking the circulation of blood and causing suffocation. Basilio, owner of the first garden depicted in the images, explains the sequence of movements:

Why roast it? Because it's raw. Manioc is strong. So roast it well. Wait for it to cool down, when you take it out of the fire. And it's going to take it to the creek, to the well, for it to soften, but not too much, or you can't put it like this [in the shape of large flatbreads].

[Pointing to the stored bread] There it's already lying down. Put it there, tomorrow or later its going to rise. It goes to the bucket. When it ripens everything is well. This one, when you lie it down, it ripens. If it doesn't ripen it stays just like the bread (beiju). It's pretty good. It doesn't become beer, but, perhaps, if you have some sugar cane juice, you take it anyway (Basílio, Ponto Cinco, 2011).

After it is placed in the bucket, it is sieved while water is added proportionally, until the beer is ready to be consumed (eleventh and twelfth images). In this vital cycle, beer is one of the manioc stem's phases of being, and it has an important role and value, since it makes the cycle start anew. During the ajuri it enlivens (anima) people for work. It condenses values: through the drink, people who do not work in the garden, who do not produce, are reprehended, while those who have the courage for work, who have many beautiful gardens, who produce plenty of high-quality beer, are singled out for praise. Those who have no garden have no beer. Community politics is critical of those who speak often when they drink beer, but who, when sober, keep silent - for example, when the mayor visits the community. People who drink until they fall over, have no knowledge of drink and no control over its effects on their body. During parties and birthdays, beer welcomes guests. In inter-community politics, it establishes important alliances. The act of offering beer can have many meanings, 
from courtesies to provocations. Beer can also be a vehicle for poisoning or for "ruining" a person. "Ruined" drink is an ever-present risk. Although politeness demands that a bowl of beer always be accepted, drinking in villages or houses that are distant from the realm of kinship, or participating in beer drinking session in the dead of night with people one is not on good terms with, is always a risky affair, since the environment in which beer is consumed is also one in which disagreements can be aired, and vengeance can be enacted.

The series of photographs above offer a visualization of the manioc stem's flow of transformations and of the forms of human-plant interactions revealed in different relational spaces and scales. In the flow of the transect, technique moves people, plants, earth, materials, energies, gestures, and knowledge, creating a properly social meshwork. These images register the same flow. They were produced in different places (gardens, yards, farina houses, ranches) and moments (work, leisure, celebrations). It is not, therefore, a sequential montage or a linear exposition. In a different way, it reveals the processual character of acts which, even if always open to the unpredictability of life, tend to consolidate a pattern, a circuit, which allows the conductors of information to accumulate and to put into circulation knowledge of alterations in soil, climate, motors, sieves, plant qualities, hearths, bowls, gatherings, birthdays - in brief, a set of knowledge that enables acts to effect changes in the course of their actions, adjust and improvise, so as to ensure that the flow keeps on the desired path, that this amplified social world be constantly generated. It is important that we are able to visualize this technical process to highlight how it can be "broken" or obliterated when people prefer to acquire things that are already made. This brings us to the third circuit, the circulation of things produced by the "whites" within communities and the contemporary social transformations that they imply.

\section{Transformations}

Throughout the Serra da Lua region there is an intense flow of people and products between communities and cities, particularly Boa Vista, the state capital. In Jacamim, the movement of residents of the community between their ranches and the community centre is closely tied to the school calendar. During weekends, school holidays and, above all, during the summer and winter breaks, the centre is mostly empty. During these times, many families take their children to their ranches. Movement between the garden, the community centre and the city of Boa Vista is also articulated by the dates in which cash-transfer benefits and wages are paid, which is generally at the start of every month. The terrible condition of the roads that connect Jacamim to the city does not favour the commercialization of surplus goods, and most of it is consumed or exchanged locally. Some of the local produce is sold in monthly markets, which take place every last Sunday of the month, with teachers being the main clients.

During the last decade, retirement funds, wages and money from cash-transfer programmes increased the purchasing power of the families of the communities. In 2011, data gathered by the Health Post revealed the presence of 40 retirees and 79 families enrolled in social programmes, out of a total of some 123 families in the community. ${ }^{6}$ On the one hand, this injection of monetary resources is considered positive. The resources aid in the acquisition of equipment and tools for developing regular activities, such as motors for manioc grating, chainsaws and ovens. It also allows for the diversification of meals, contributing toward food security in cases in which food production suffers, which are increasingly common with climate change. On the other hand, many inhabitants of the community are perceiving changes in social values that stem from this monetization. Mr Estevão analyses the dynamics of comings and goings into the city, and the growing consumption of food that is not produced locally.

6 The Programa Bolsa Família (PBF, Family Stipend Programme), created in 2004 by law $n^{\circ} 10,836$, is a cash-transfer programme that benefts families in states of poverty and extreme poverty in Brazil. For further information on the PBF, see http://www.mds.gov.br/bolsafamilia 
A: When you go into town, you buy food to last for how long?

E: For two months. Then I go every two months. Some people go every month. I'm going this month. In the winter that's how it is, I go every two months. It's May now right? Then I'll only go back in July. I almost never lack food. I just go to buy rice, you know, spaghetti. Maybe some soap, like, I go to the city. But farina and these things... We make them here, to eat.

A bunch of people don't know to buy food, but they don't like making gardens, so they go to Boa Vista to buy farina. I never buy farina, I've been retired for 12 years, never bought farina. We can plant manioc stems right? You can buy eggs, rice, spaghetti, these things. I just planted, day before yesterday, I have a garden with eight rows and seven rows, of stems.

I also planted maize. There are new people here who don't like to work anymore in the gardens. I have a brotherin-law, he's retired, doesn't work in the garden, buys farina, everything, in Boa Vista. "My garden is Boa Vista”, he says. (Mr Estevão, Jacamim, 2011)

Reflecting on these transformations, Eliezer, which works as an Indigenous Health Agent (Agente Indígena de Saúde, AIS) in the Marupá community, observes that his kinspeople want to eat things that are already made, nobody knows anything about doing. According to him, this began with the Federal government which, at first with retirement pensions and later with cash-transfer programmes, got people accustomed. Among the ensuing effects, he notes that people don't want to work in the gardens anymore, they just wait for payday (...) end of the month they just want to go into Boa Vista (...) This is what change is: food and planting. As he works in the health sector, Eliezer pays attention to changes in people's clinical condition: "We already find disease from there, from the food of the whites, we don't know how to use it, we don't know how to eat the food of the whites, we want to eat it like we eat our food and the community hurts itself because of this as well".

On the one hand, these issues raised here bring us to a debate concerning the growing importance of local agricultural systems in international discussions on the maintenance and insurance of the diversity of food production in the world, and the role of agriculturalists. On the other, locally these elements make evident how the flow of products and monetary resources interfere in the community and the resilience of these systems. Most of all, they draw attention to the effects of the circulation of industrialized foodstuffs in the communities, both in what concerns the health of people and the quality of their daily relations.

These local impressions raise important questions about the transformation of traditional agricultural systems in Amazonia and the local answers to the logic of the market. In studies on the agricultural diversity of the Rio Negro, Eloy and Emperaire (2008) show the resilience with which the local systems for managing biodiversity react to the new conditions of space, biological vulnerability, and the social and economic issues linked to its reproduction. In general, this agriculture is extremely rich in plant diversity, in associated knowledge practices, and is crucial for its central role in food security for families, with manioc being an example of genetic diversity that has been preserved and controlled by Indigenous horticulturalists for millennia, through their experimentations, selections and breeding.

The rhetoric of valuing traditional knowledge that underscores a public plea for the value of these productive systems is still timid in terms of its effect in the area of the Brazil-Guyana border, when contrasted to the sharply unequal relations between the people who develop these traditional practices and the socioeconomic regional flows that threaten them. One result of this has been the devaluation of the former as a result of the lure of urban lifestyles and access to agricultural produce through financial resources. This, as I see it, is the thrust of Mr Estevão's and Eliezer's critique of social transformation, access to social benefits offered by the Federal government and their moral reflexes, the devaluation of garden work and health effects for people who start to eat "ready-made" products, acquired in supermarkets, forfeiting knowledge practices. 
This line of Indigenous analysis resonates the importance of technical processes, not only in the sense of producing food, but also as processes that imply relations of cooperation between people who are the strength for the continuity of a sense of community. As the description of the different circuits seems to reveal, these socioeconomic transformations alter complex relational networks which are not restricted to humans, and which generate valuable knowledge of a category of edible plants. Interferences along the networks of relation affect these ways of knowing, tending to paralyze processes which are vital the very existence of whole communities. Beneath these processes, there is a permanent technogenesis of the social.

\section{Final Thoughts}

Throughout this article, I have sought to circumscribe the intersections of technical processes and vital flows in human-pant relations in the context of pluriethnic communities in the Serra da Lua region, on the border between Brazil and Guyana. My ethnographic aim has been to make visible the techniques through which the Indigenous communities handle this plant, and, in so doing, construct collectivities. The study of techniques offers certain conceptual and methodological tools for describing how these plants are transformed into components of a way of producing food and relations.

In this field, the notion of the "operational sequence" is a basic tool for registering series of operations involved in any transformation of matter by human beings. A focus on "action upon matter" establishes a methodological delimitation of the very object of study, which helps to delineate technical processes, but use of the word "upon" retains an anthropocentric character and leaves other modalities of "actions" vague. The human-plant relation represented here raises questions for this formula, since it consists of flows in which humans act upon manioc stems and these act back in different ways, depending on the phases of the stem's very being, because the stem is not passive material, according to the Indigenous explanations of the vital processes of this plant.

Elaborating an operational sequence that incorporates every detail of the technical process can turn out to be an unviable, and probably unproductive, methodological strategy. It falls to the researcher to find a form or representation adapted to the sort of activity and the type of question under study. As Coupaye proposes, the operational sequence is not a methodological resource that objectifies an exhaustive or complete description. It is a form of ethnographic composition that enables the visualization of how a technical process mobilizes a network, and it is useful for adding to the description and allowing the development of inferences concerning different vital circuits. This "sequence" should not be taken as a prescriptive model, since cultivation, for example, always has an unpredictable character and involves aspects such as continuous mindfulness, care, judgment and improvisation. The operational sequence as a transect is a type of formalization which does not correspond to an abstract, prescriptive or deterministic model. It establishes a profile, and the limitations of this sort of procedure are themselves informative, confirming the fact that, at the methodological margins, interesting properties of the phenomena being studied can become visible (Coupaye 2009), or, in Simondonian terms, can illuminate their "obscure zones".

The anthropological analysis of techniques consists of understanding human ways of relating to material, not just in acts of production, but also as mediators in the life of humans and animals through mutually constituting relational flows. Haudricourt (2013 [1962]) has offered us valuable insights that qualify contemporary studies of human-nonhuman relations. A botanist, anthropologist and linguist, Haudricourt proposed two models of action that affects plants, animals and humans. Taking the examples of yam cultivation in Melanesian New Caledonia and sheep husbandry in the Mediterranean, he observed that while cultivation of the tuber is a form of indirect action - which seeks to create the conditions for the realization of the plants' 
potentialities and does not require "brutal contact in space nor simultaneity in time with the domesticated being" (2013: 2), sheep husbandry requires positive direct action - the permanent contact of shepherd with the domesticated being.

This proposal was developed by Carole Ferret (2012), who has sought to analyse ways of acting as different forms of inter-action between humans and nonhumans. In Ferret's terms, while in an operation the subject acts upon an object with the aim of achieving a goal, in manipulation the form of action includes the potential for the actions of plants and animals, making them also act with the aim of achieving a goal.

In this perspective, technique is always relational and its analysis must always provide room for the perspective of plants, for instance. These ideas are in dialogue with an ecological perspective, in which plants are not considered inert material, finished and crystallized, but living beings the properties of which are condensed in histories of what happens to them as they flow, mix and transform (Ingold 2011), in their interactions with humans. The technical process of manipulating the stems jumbles up these terms, for it involves both direct positive and indirect negative acts - and, we can venture, it includes its converse, since plants directly and indirectly make humans act with the aim of achieving their own vital goals. This is what I mean by a technogenesis of the social. Hence, to opt for ready made things is to break the flow of this vital relation for both humans and plants, demobilizing the ontogenetic processes of a sense of community.

Submitted: August 26, 2018

Approved: September 13, 2019

Translated by Luiz Costa (luizcosta10@gmail.com) 


\section{Bibliography}

ÁVILA, Thiago A. M. de. 2006. "Biopirataria e os Wapichana: etnografia sobre a bioprospecção e o acesso aos recursos genéticos na Amazônia Brasileira." Revista de Estudos e Pesquisas, 3(1/2): 225-26o.

BAINES, Stephen G. 2005. "Indigenous autonomies and rights on the Brazil-Guyana border: makushi and Wapichana on an internacional border". Série Antropologia, 386: 2-13

BARNES, John. 1987. "Redes sociais e processos políticos”. In: B. Feldman-Bianco (org.), Antropologia das Sociedades Contemporâneas. São Paulo: Global Editora. pp. 159-193.

BARTH, Fredrik. 1987. Cosmologies in the Making: A Generative Approach to Cultural Variation in Inner New Guinea. Cambridge: Cambridge University Press.

. 1995. "Other Knowledge and Other Ways of Knowing”. Journal of Anthropological Research, 51(1): 65-68. . 2000. "O guru e o iniciador: transações de conhecimento e moldagem da cultura no sudeste da Ásia e na Melanésia”. In: O guru, o iniciador e outras variações antropológicas. J. C. Comerford [trad.].

Rio de Janeiro: Contra Capa. pp. 141-165.

CHERNELA, Janet M. 1987. “Os cultivares de mandioca na área do Uaupés (Tukano)”. In: D. Ribeiro (ed.), Suma Etnológica Brasileira. Petrópolis: Vozes. vol. 1. 2ª ed. 151-158

CIR/PDPI/MMA. 2006. Sementes tradicionais: passado, presente e futuro. Cultive! Brasília: PDPI/MMA.

CRESSWELL, R. 1973. "Technologie Culturelle”. Encyclopaedia Universalis, 15: 823-28.

COLSON, Audrey B. 1985. "Routes of knowledge: an aspect of regional integration in the circum-Roraima area of the Guiana Highlands". Antropológica, 63-64: 103-149

COUPAYE, Ludovic. 2009. "Ways of enchanting: Chaînes Operatoire and Yam Cultivation Nyamikum Village, Maprik, Papua New Guinea”. Journal of Material Culture, 14(4): 433-458.

. 2016. "Yams as Vernacular Methodology? Approaching Vital Processes through Technical Processes".

In: Des êtres vivants et des artefacts. [En ligne]. mis en ligne le 20 janvier 2016, consulté le 12 juillet 2018.

URL : http://journals.openedition.org/actesbranly/673

ELOY, L.; EMPERAIRE, Laure. 2008. “A cidade, um foco de diversidade agrícola no Rio Negro (Amazonas, Brasil)". Boletim do Museu Paraense Emilio Goeldi, 3: 195-211.

EMPERAIRE, Laure. 2001. "Elementos de discussão sobre a conservação da agrobiodiversidade: o exemplo da mandioca (Manihot esculenta Crantz) na Amazônia brasileira”. In: Joao Paulo Capobianco (org.), Biodiversidade na Amazônia brasileira: avaliação e ações prioritárias para a conservação, uso sustentável e repartição de benefícios. Sao Paulo: Estação Liberdade / ISA. pp. 225-234.

. 2002. "Agrobiodiversidade em risco: o exemplo das mandiocas na Amazônia".

Ciência Hoje, 32(187): 28-33.

. 2010. "História da Vida das Plantas e Agricultura Indígena no Médio e Alto Rio Negro". In: A.

Cabalzar (org.), Manejo do Mundo: conhecimentos e práticas dos povos indígenas do rio negro.

São Paulo: ISA.192-203

EMPERAIRE, L.; VELTHEM, L. V.; OLIVEIRA, A. G. 2008. "Patrimônio Cultural Imaterial: O manejo da diversidade agrícola no médio rio negro Amazonas.” Trabalho apresentando na 26a Reunião Brasileira de Antropologia, Porto Seguro, Bahia, Brasil. Mimeo.

FAGUNDES, Guilherme Moura. 2014. Recursos e Patrimônios. matéria e forma nas políticas da agrobiodiversidade. Dissertação de mestrado - Programa de Pós-Graduação em Antropologia Social do Departamento de Antropologia da Universidade de Brasília.

FARAGE, Nádia. 1997. As flores da fala: práticas retóricas entre os Wapichana. FFLCH/USP: Tese de doutorado apresentada à Área de Estudos Comparados em Literaturas de Língua portuguesa. 
. 2002. "Instruções para o presente. Os brancos em práticas retóricas Wapishana". In: Bruce Albert e Alcida Rita Ramos (eds.), Pacificando o Branco: cosmologias do contato no orte-amazônico/organizadores. São Paulo: Editora UNESP: Imprensa Oficial do Estado. 507-531

FERRET, Carole. 2012. "Towards an anthropology of action: from pastoral techniques to modes of action". Journal of Material Culture, 19(3): 279-302.

GALLOIS, Dominique Tilkin (org.). 2005. Redes de relações nas Guianas. São Paulo: Associação Editorial. Humanitas: Fapesp.

HAUDRICOURT, André-Georges. 2013 [1962].. Domesticação de animais, cultivo de plantas e tratamento do outro. Série Tradução. Brasília: Departamento de Antropologia, UnB,

INGOLD, Tim. 2000. The Perception of the Environment: Essays on livelihood, dwelling and skill. London and New York: Routledge. . 2011. Materials against materiality. In.: Being Alive: essays on movement, knowledge and description. Oxford: Routledge. . 2012 "Trazendo as coisas de volta à vida: Emaranhados criativos num mundo de materiais".

Horizontes Antropológicos, 18(37): 25-44. . 2015. Estar vivo: ensaios sobre movimento, conhecimento e descrição. Tradução de Fábio Creder.

Petrópolis, RJ: Vozes.

LATOUR, Bruno. 1994. Jamais fomos modernos. Coleção Trans. Rio de Janeiro, 1a Edição: Editora 34. . 2005. Reassembling the Social: An Introduction to Actor-Network-Theory. Oxford/New York:

Oxford University Press.

LEACH, Edmund Ronald. 1996 [1954]. Sistemas Políticos da Alta Birmânia: um estudo da estrutura social Kachin. São Paulo: Editora da Universidade de São Paulo.

LEMONNIER, Pierre. 1986. "The Study of Material Culture Today: Toward an Anthropology of Technical Systems”. Journal of Anthropological Archaeology, 5: 147-186. . 1992. Elements for an Anthropology of Technology. Ann Arbor: University of Michigan Press. (ed.). 1993. Technological Choices: Transformation in Material Culture since the Neolithic.

London: Routledge.

MAUSS, Marcel. 2003 [1935]. "As técnicas do corpo". In: Sociologia e Antropologia. São Paulo: Cosac Naify. pp. 399-420. . 2009. Techniques, technology and civilization. New York: Berghahn Books.

MELATTI, Júlio. 2010. “Guianense Ocidental”. In: Índios da América do Sul - Áreas Etnográficas. manuscrito MURA, Fabio. 2011. "De sujeitos e objetos: um ensaio crítico de antropologia da técnica e da tecnologia". Horizontes Antropológicos, 17(36): 95-125.

OVERING, Joana. 1991. "A estética da produção: o senso da comunidade entre os Cubeo e os Piaroa". Revista de Antropologia, 34, 7-33: 7-34.

OLIVEIRA, Alessandro Roberto de. 2012. Tempo dos netos: abundância e escassez nas redes de discursos ecológicos entre os Wapichana na fronteira Brasil-Guiana. Tese de Doutorado. Departamento de Antropologia-UnB, 2012.

OLIVEIRA, Alessandro Roberto de.2015 "De plantas, peixes e parentes: técnica e cosmologia no debate sobre a pesca com timbó entre os wapichana na região serra da lua, Roraima. Amazônica - Revista de Antropologia, [S.l.], v. 7, n. 1, p. 28-49

OLIVEIRA, Alessandro Roberto de. 2018. "Técnicas de estragar os outros: sobre a ética xamânica na fronteira Brasil-Guiana”. Horizontes Antropológicos, 24(51), 51-78. https://dx.doi.org/10.159o/s0104-71832018000200003 
PITROU, Perig. 2016. “Ação ritual, mito, figuração: imbricação de processos vitais e técnicos na Mesoamérica e nas terras baixas da América do Sul (Introdução)”. Revista de Antropologia, 59(1): 6-32.

PINHO, Raquel Camargo de. 2008. Quintais Agroflorestais indígenas em área de savana (Lavrado) na terra indígena Araça, Roraima. Dissertação de Mestrado INPA/UFAM, Manaus.

RIVIÈRE, Peter. 2006. [1984] O indivíduo e a sociedade na Guiana: um estudo comparativo sobre a organização social ameríndia. São Paulo: Editora da Universidade de São Paulo.

SANTILLI, Juliana. 2012. "A Lei de Sementes brasileira e seus impactos sobre a agrobiodiversidade e os sistemas agrícolas locais e tradicionais". Boletim Museu Paraense Emilio Goeldi, 7: 457-475.

SANTILLI, Paulo. 1994. Fronteiras da República: história e política entre os Macuxi no vale do rio Branco. São Paulo: NHII-USP/ FAPES.

SAUTCHUK, Carlos. 2015. "Aprendizagem como gênese: prática, skill e individuação”. Horizontes Antropológicos, 21(44): 109-139.

SIGAUT, François. 2002 “Technology”. In: Tim Ingold (ed.), Companion Encyclopedia of Anthropology. London: Routledge. pp. 420-59.

SIMONDON, Gilbert. 2005 [1958]. "Introduction”. In: L'individuation à la lumière des notions de forme et d’information. Paris: Édition Jérôme Millon. pp. 23-36

VELTHEM, Lucia. 2012. "Cestos, peneiras e outras coisas: a expressão material do sistema agrícola no rio Negro”. Revista de Antropologia, 55(1): 401-438

VIVEIROS DE CASTRO, Eduardo. 1986. "Sociedades minimalistas: A Propósito de um livro de Peter Rivière". Anuário Antropológico, 10(1): 265-282.

Alessandro Roberto de Oliveira

University of Brasília (UnB), Brasília/DF, Brazil

https://orcid.org/0000-0003-4390-2883

Author's e-mail: alessandrooliveira@unb.br 